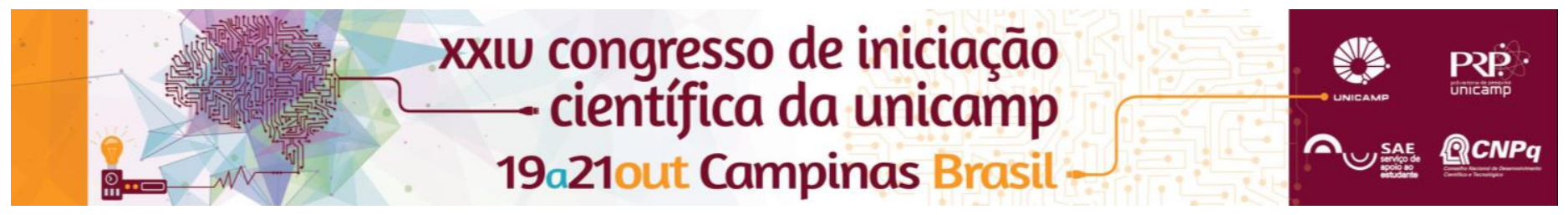

\title{
Mulheres na economia solidária. Trabalho e inserção nas cooperativas de materiais recicláveis.
}

\section{Gisele A. S. Augusto.}

\section{Resumo}

Este projeto se propôs analisar as relações inerentes à inserção das mulheres no meio produtivo solidário, especificamente em uma cooperativa de materiais recicláveis da cidade de Campinas/SP. Os empreendimentos solidários que atuam na área de reciclagem costumam ser pensados como práticas econômicas mais sustentáveis que aliam geração de renda e preservação do meio ambiente. A pesquisa teve como pontos fundamentais, a observação participante e a aplicação de entrevistas, visando à apreensão das percepções das agentes quanto as suas experiências no ambiente de trabalho, principalmente nos aspectos econômicos, sociais e familiares. A autogestão é objetivo principal das cooperativas inseridas na Economia Solidária. Portanto, um pilar deste trabalho é a análise do grau de participação e autonomia das trabalhadoras na gestão do empreendimento. O segundo pilar deste estudo diz respeito à estrutura familiar das trabalhadoras e suas redes sociais, segundo o ponto de vista delas próprias, destacando os pontos positivos e negativos decorrentes do trabalho em questão.

\section{Palavras-chave:}

Mulheres, economia solidária, trabalho.

\section{Introdução}

A precarização do trabalho e as novas configurações familiares trouxeram à tona dilemas complexos para as mulheres, relacionados principalmente com a conciliação entre trabalho remunerado, casa, cuidados com a família, estudos, carreira, saúde, etc. Para uma grande parcela dessas mulheres, o primeiro obstáculo a ser ultrapassado é garantir uma posição no mercado de trabalho e consequentemente a sua subsistência e de seus familiares (LEITE e RODRIGUES; 2015).

Uma das alternativas de trabalho que ganha cada vez mais espaço no mercado é a Economia Solidária, baseada em princípios de ação coletiva, solidariedade e reciprocidade. As cooperativas de materiais recicláveis se inserem nesta economia plural, que apesar dos princípios solidários, ainda esbarra em grandes desafios para sua concretude (GAIGER e LAVILLE; 2009).

\section{Objetivos}

$\checkmark \quad$ Analisar o espaço laboral, social e familiar de mulheres que trabalham com materiais recicláveis.

$\checkmark \quad$ Conhecer suas percepções sobre condição econômica, político-participativa, pessoal e familiar $\checkmark \quad$ Compreender suas dificuldades, desafios e conquistas.

\section{Metodologia \\ $\checkmark \quad$ Observação participante; \\ $\checkmark \quad$ Aplicação de questionários; \\ $\checkmark \quad$ Entrevistas na residência das trabalhadoras.}

Figura 1. Trabalhadoras da pré-triagem.

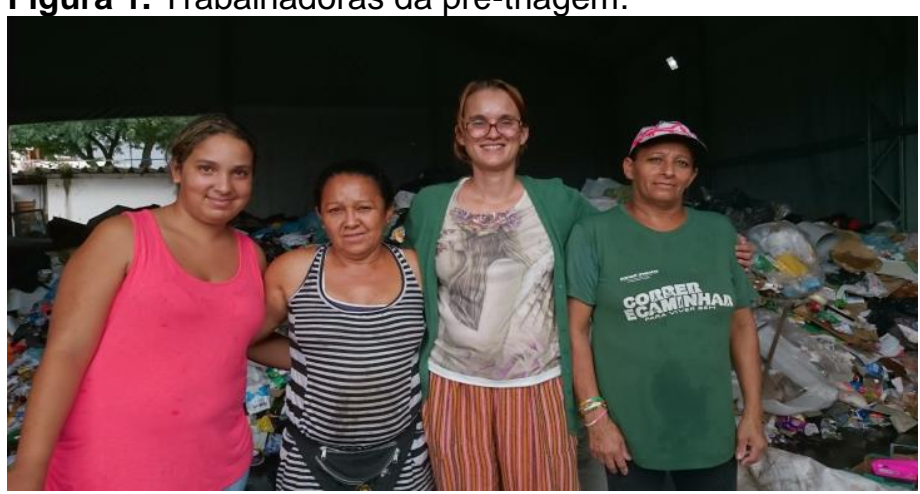

\section{Resultados}

$\checkmark \quad$ Os requisitos para contratação são mínimos;

$\checkmark \quad$ Existe abertura para trabalhadores (as) sem qualificação ou escolaridade;

$\checkmark \quad$ Não importa os antecedentes criminais;

$\checkmark \quad$ O trabalho laboral é difícil e extenuante;

$\checkmark$ Não existem equipamentos básicos de segurança;

Infraestrutura para alimentação e higiene são precárias;

$\checkmark$ Remuneração baixa (média de $\mathrm{R} \$ 600,00$ mensais);

$\checkmark \quad$ Vale-transporte é pago apenas no segundo mês de trabalho;

Percentual alto de analfabetas e em idades avançadas;

$\checkmark \quad$ Mulheres com histórico de violência doméstica;

$\checkmark \quad$ Autogestão precária;

$\checkmark \quad$ Hierarquização;

$\checkmark \quad$ Alta rotatividade entre as trabalhadoras;

$\checkmark \quad$ Reprodução da divisão sexual do trabalho.

\section{Conclusões}

Apesar dos grandes desafios de inclusão e permanência das trabalhadoras, vale destacar que esta é a alternativa que viabiliza o exercício de atividade remunerada no caso de mulheres com características desvalorizadas pelo mercado: idade, baixa escolaridade e qualificação não são impecílios para que elas possam desenvolver suas atividades, embora careçam sobremaneira de um amparo mais eficaz do Poder Público.

\section{Agradecimentos}

Agradeço primeiramente a essas mulheres guerreiras, a minha orientadora Joice Melo Vieira e ao CNPq.

GAIGER, L. I.; LAVILLE, J.L. Economia solidária. In: CATTANI, Antonio et al. (Orgs.). Dicionário internacional da outra economia. Coimbra: Almedina, 2009

LEITE, M. de PAULA; RODRIGUES, C.C. PONTES. Trabalhadores e trabalhadoras em empreendimentos Solidários: Perfil e Representações. In: LEITE, M.de PAULA; ARAÚJO, A. M. C; LIMA, J.C. O trabalho na Economia Solidaria - Entre a precariedade e a emancipação. São Paulo. Annablume, 2015. (p. 163-201) 